\title{
Hubungan Status Ketahanan Pangan Rumah Tangga dengan Anemia pada Ibu Hamil (Studi di Desa Bektiharjo Kecamatan Semanding Kabupaten Tuban)
}

\author{
Association between Household Food Security and Anemia among \\ Pregnant Women (Study in Bektiharjo Village, Semanding Sub-district, \\ Tuban District)
}

Erike Duwi Nurdini*1 ${ }^{*}$ Trias Mahmudiono ${ }^{2}$

\begin{abstract}
ABSTRAK
Latar Belakang: Peningkatan potensi anemia pada masa kehamilan dapat dilihat dengan adanya peningkatan prevalensi anemia ibu hamil yang tinggi di Indonesia. Pemenuhan kebutuhan zat gizi kehamilan dapat dipengaruhi oleh kemampuan ekonomi yang dapat dilihat dari ketahanan pangan rumah tangga ibu hamil.

Tujuan: Penelitian ini bertujuan untuk mengetahui hubungan antara status ketahanan pangan rumah tangga dengan anemia pada Ibu Hamil.

Metode: Penelitian ini menggunakan rancangan desain cross sectional dengan besar sampel sebanyak 50 ibu hamil di Desa Bektiharjo Kecamatan Semanding Kabupaten Tuban. Ketahanan pangan rumah tangga diukur menggunakna instrumen kuesioner US-HFSSM, sedangkan kadar hemoglobin diukur menggunakan alat digital Easy Touch GCHb. Uji statistik menggunakan uji korelasi pearson.

Hasil: Penelitian ini menunjukkan adanya hubungan yang signifikan antara status ketahanan pangan rumah tangga dengan anemia pada ibu hamil ( $\mathrm{p}=0,019$; $\mathrm{OR}=-0,331)$.

Kesimpulan: Berdasarkan hasil penelitian disimpulkan bahwa terdapat hubungan yang signifikan antara status ketahanan pangan rumah tangga dengan anemia pada ibu hamil. Peningkatan konsumsi makanan sumber zat besi non heme dan enhancer zat besi dengan harga terjangkau disarankan untuk ibu hamil terkait dengan kondisi kerawanan pangan rumah tangga.
\end{abstract}

Kata kunci : ketahanan pangan rumah tangga, anemia, ibu hamil

\begin{abstract}
Background: The raise of anemia potential in pregnancy can be reflected by the increase of high anemia prevalence among pregnant woman in Indonesia. Meeting the nutritional needs in pregnancy can be influenced by the prosperity that can be seen from household food security of pregnant women.

Objectives: The aim of this research was to know the relationship between household food security status with anemia among pregnant women

Methods: This research was using cross-sectional design with 50 pregnant women who lived in Bektiharjo Village Semanding Sub-District Tuban District as the sample. US-HFSSM questionnaire was used as the instrument of household food security status while the level of haemoglobin was measured by Easy Touch GCHb digital device.

Results: The result showed there was a significant relationship between household food security status with anemia among pregnant women $(p=0.019 ;$ OR=-0.331). Pearson Correlation test was used as statistical test for this study.

Conclusions: Based on the result of this research there was a significant correlation between household food security status with anemia among pregnant women. Increasing consumption of affordable foods that contain non-heme iron and iron enhancer is recommended for pregnant women related to household food insecurity.
\end{abstract}

Keywords : household food security, anemia, pregnant women 
*Koresponden :

erike.duwi98@gmail.com

1Prodi S1 Gizi, Fakultas Kesehatan Masyarakat Universitas Airlangga, Kampus C Mulyorejo, 60115,

Surabaya, Indonesia

${ }^{2}$ Departemen Gizi Kesehatan, Fakultas Kesehatan Masyarakat Universitas Airlangga, Kampus C

Mulyorejo, 60115, Surabaya, Indonesia

\section{PENDAHULUAN}

Pangan merupakan salah satu kebutuhan pokok manusia dalam menjaga kelangsungan hidup. Pemenuhan kebutuhan pangan merupakan hal yang penting bagi negara hingga tingkat individu yang kemudian disebut dengan ketahanan pangan dan telah diatur dalam Undang-Undang Nomor 18 Tahun 2012 tentang pangan.('No title' 2012) Ketahanan pangan juga merupakan bagian penting dari pembangunan negara karena telah tercantum dalam beberapa poin di SDGs (Sustainable Development Goals) yang disepakati oleh United Nations Development Programme pada tahun 2015 terkait dengan pemberantasan kelaparan.(Fan \& Brzeska 2016) Ketahanan pangan tidak lepas dari kemampuan untuk mengakses bahan pangan.

Akses pangan dapat berpengaruh terhadap tercapainya ketahanan pangan, khususnya dari segi ekonomi atau kesejahteraan yang meliputi pendapatan, kesempatan kerja, dan harga pangan.(Yusuf 2011) Kemampuan ekonomi penduduk pedesaan cenderung lebih rendah dibandingkan perkotaan. Ditinjau dari data BPS jumlah penduduk miskin di Jawa Timur pada Maret 2018 mencapai angka 4.332,59 ribu jiwa dengan proporsi penduduk miskin di pedesaan dua kali lipat lebih banyak dari perkotaan.(Timur 2018)

Lokasi penelitian di Kabupaten Tuban merujuk data BPS yang menunjukkan angka kemiskinan mencapai 196.100 jiwa atau sekitar 16,87\% pada Maret 2017.(Pada 2018) Angka ini menduduki posisi kelima untuk kategori kabupaten dengan jumlah penduduk miskin terbesar di Jawa Timur pada periode tersebut. Ditinjau dari data kemiskinan, penduduk Tuban berpotensi untuk mengalami kecenderungan keterbatasan akses terhadap pangan khususnya kelompok pangan hewani. Hal ini dikarenakan harga pangan hewani cenderung lebih mahal dibandingkan dengan bahan makanan lainnya.(Perdagangan et al. 2014) Tingkat konsumsi pangan hewani di pedesaan juga dinilai cenderung rebih rendah dibandingkan perkotaan.(Fitri et al. 2016) Pangan hewani merupakan kelompok pangan kaya gizi, salah satunya adalah sumber Fe yang baik.(Furkon, Perlu \& Ilmu 2014) Zat besi atau Fe erat kaitannya dengan masalah anemia. Potensi masalah anemia meningkat pada masa kehamilan. Hal ini dapat dilihat melalui peningkatan proporsi anemia ibu hamil di Indonesia pada tahun 2013 sebesar 37,1\% menjadi 48,9\% pada tahun 2018 (Riskesdas, 2018).(RI 2018) Masalah anemia kehamilan ini juga masih ditemukan di Desa Bektiharjo Kecamatan Semanding.

Berdasarkan latar belakang dilakukannya peneliti ini adalah untuk mengetahui hubungan antara status ketahanan pangan rumah tangga dengan anemia pada Ibu Hamil di Desa Bektiharjo Kecamatan Semanding Kabupaten Tuban.

\section{METODE}

Penelitian ini merupakan penelitian observasional yakni melakukan pengamatan secara langsung kepada responden penelitian tanpa pemberian intervensi apapun, dengan rancangan desain cross sectional karena pengamatan kepada setiap responden hanya dilakukan dalam sekali waktu. Populasi target yang terjangkau dalam penelitian ini yaitu ibu hamil yang tinggal di Desa Bektiharjo di Kecamatan Semanding, Kabupaten Tuban.

Berdasarkan data Puskesmas Semanding hingga bulan April 2019, yakni terdapat sebanyak 50 ibu hamil yang tinggal di Desa Bektiharjo. Sampel dalam penelitian ini merupakan non probability sample menggunakan teknik total sampling, yakni jumlah sampel sama dengan jumlah populasi. Hal ini dikarenakan jumlah populasi yang kurang dari 100 orang, sehingga seluruhnya perlu dijadikan responden (Arikunto, 2013).(Ariani et al. 2018)

Penelitian ini telah dinyatakan lolos etik dengan nomor 421/HRECC.FODM/VII/2019 dari komisi etik Fakultas Kedokteran Gigi Universitas Airlangga. Data primer didapatkan dari hasil wawancara menggunakan kuesioner sedangkan data sekunder diperoleh dari Puskesmas Semanding. Penentuan status ketahanan pangan rumah tangga melalui penggunaan kuesioner US-HFSSM (United States Household Food Security Survey Module) sebagai instrumen sedangkan status anemia diketahui melalui uji kadar hemoglobin menggunakan alat ukur digital (Easy Touch GCHb). 
Penyajian data dalam bentuk tabel distribusi karakteristik responden dan tabulasi silang antara status ketahanan pangan rumah tangga dengan anemia pada ibu hamil. Status ketahanan pangan rumah tangga disajikan menggunakan skala data ordinal, sedangkan anemia dikategorikan menjadi data nominal. Analisis menggunakan uji statistk korelasi pearson untuk mengetahui signifikansi hubungan kedua variabel dengan nilai $\alpha=0,05$.

\section{HASIL DAN PEMBAHASAN}

Karakteristik responden dapat dilihat melalui tabel 1 yang memuat beberapa variabel yakni usia ibu hamil, usia kehamilan, pendapatan rumah tangga, kadar hemoglobin dan juga status ketahanan pangan rumah tangga. Berdasarkan usia, diketahui sebagian besar responden berada pada usia reproduksi sehat yakni sebanyak 76\%. Usia kehamilan didominasi oleh kehamilan trimestester 3 sebanyak $44 \%$. Berdasarkan riwayat pendidikan formal yang dimiliki, persentase paling banyak ada pada ibu hamil lulusan SMP yakni 48\%. Adapun jika ditinjau dari pendapatan total rumah tangga, sebagian besar reponden $(40 \%)$ berada di kuintil 2 yaitu kategori pendapatan antara Rp 1.680.000,1 hingga Rp 2.160.000.

Tabel 1. Distribusi Karakteristik Ibu Hamil di Desa Bektiharjo Tahun 2019

\begin{tabular}{|c|c|c|}
\hline Variabel & $\mathbf{n}$ & $\%$ \\
\hline \multicolumn{3}{|l|}{ Usia Responden } \\
\hline$\leq 19$ tahun & 3 & 6 \\
\hline $20-35$ tahun & 38 & 76 \\
\hline$>35$ tahun & 9 & 18 \\
\hline \multicolumn{3}{|l|}{ Usia Kehamilan } \\
\hline Trimester 1 & 10 & 20 \\
\hline Trimester 2 & 18 & 36 \\
\hline Trimester 3 & 22 & 44 \\
\hline \multicolumn{3}{|l|}{ Pendapatan Rumah Tangga } \\
\hline Kuintil 1 & 12 & 24 \\
\hline Kuintil 2 & 20 & 40 \\
\hline Kuintil 3 & 10 & 20 \\
\hline Kuintil 4 & 7 & 14 \\
\hline Kuintil 5 & 1 & 2 \\
\hline \multicolumn{3}{|l|}{ Riwayat Pendidikan } \\
\hline SD & 14 & 28 \\
\hline SMP & 24 & 48 \\
\hline SMA & 12 & 24 \\
\hline \multicolumn{3}{|l|}{ Kadar Hemoglobin } \\
\hline$<11 \mathrm{~g} / \mathrm{dl}$ & 16 & 32 \\
\hline$\geq 11 \mathrm{~g} / \mathrm{dl}$ & 34 & 68 \\
\hline \multicolumn{3}{|l|}{ Status Ketahanan Pangan Rumah Tangga } \\
\hline Tahan pangan & 27 & 54 \\
\hline Rawan pangan tanpa kelaparan & 19 & 38 \\
\hline Rawan pangan dengan kelaparan tingkat sedang & 4 & 8 \\
\hline Rawan pangan dengan kelaparan tingkat berat & 0 & 0 \\
\hline
\end{tabular}

Hasil penelitian ini menunjukkan bahwa sebagain besar responden adalah rumah tangga yang tahan pangan. Hal ini berdasarkan tabel 1 yang menyatakan bahwa lebih dari setengah jumlah responden memiliki status tahan pangan (54\%). Selain itu juga sisanya merupakan rumah tangga yang rawan pangan (46\%). Namun tidak ditemukan adanya rumah tangga yang mengalami rawan pangan dengan kelaparan tingkat berat. Ketahanan pangan suatu rumah tangga dapat dipengaruhi oleh beberapa faktor, khususnya akses pangan yang cenderung dipengaruhi oleh pendapatan. Hal ini terkait dengan proporsi pengeluaran untuk pangan dari total pendapatan yang dimiliki.(Situasi \& Masyarakat 2008) Berdasarkan data yang telah diperoleh menunjukkan bahwa responden cenderung berada pada kategori pendapatan yang cukup rendah. Hal ini diketahui bahwa hanya sebagian kecil pendapatan responden yang berada di kuintil 4 dan 5 . 
Pendapatan rumah tangga berkaitan dengan kemampuan akses pangan untuk pemenuhan kebutuhan gizi.(Maret 2011) Khususnya untuk bahan makanan tertentu yang memiliki nilai ekonomi relatif tinggi seperti protein hewani.(Suryanty \& Reswita 2016) Selain dari segi ekonomi, pola konsumsi sehari-hari juga dapat dipengaruhi oleh wawasan atau pengetahuan.(Diana Sukmaningtiyas 2015) Tingkat pendidikan ibu hamil dapat dijadikan salah satu indikator untuk mengetahui daya terima informasi gizi yang memungkinkan didapatkan selama kehamilan.(Kusuma, Khomsan \& Kustiyah 2017) Menurut data yang diperoleh hanya sebagian kecil responden yang lulus SMA (24\%), sedangkan sisanya adalah tamatan SD dan SMP, sehingga tergolong riwayat pendidikan yang rendah. Oleh karena itu pendapatan dan pendidikan dapat dijadikan pertimbangan dalam pemilihan jenis makanan untuk dikonsumsi. Makanan sumber zat besi heme maupun non heme sangat diperlukan untuk memenuhi peningkatan kebutuhan zat besi saat kehamilan yang berasal dari pangan hewani dan nabati. Selain itu, bahan makanan yang banyak mengandung vitamin $\mathrm{C}$ juga baik dikonsumsi oleh ibu hamil karena dapat digolongkan sebagai enhancer penyerapan zat besi.(Anemia 1989) Jenis bahan pangan lain yang perlu diperhatikan oleh ibu hamil adalah makanan ataupun minuman yang mengandung tanin seperti teh dan kopi karena berperan sebagai inhibitor atau penghambat penyerapat zat besi.(Access 2018)

Makanan sumber hewani mengandung sumber zat gizi yang baik dan diperlukan oleh manusia, termasuk zat gizi mikro seperti zat besi (Fe).(Furkon, Perlu \& Ilmu 2014) Terdapat sekitar 40\% zat besi heme berasal dari pangan hewani, dengan ketersediaan biologis yang baik yakni sekitar 23\% (Du et al. 2000), sehingga zat gizi lebih mudah diserap dan dimanfaatkan oleh tubuh. Kandungan zat besi pada bahan makanan tersebut sangat diperlukan terutama untuk ibu hamil, karena pada masa kehamilan kebutuhan akan zat besi mengalami peningkatan. Zat besi juga disebutkan sebagai salah satu zat gizi mikro yang penting dalam masa kehamilan yang tercantum pada pesan khusus gizi seimbang.(Seimbang 2014) Hal ini berkaitan dengan bertambahnya massa sel darah merah dan volume plasma serta persiapan kehilangan zat besi saat melahirkan.(Fitri et al. 2016; Maternal et al. 2019) Oleh sebab itu ibu hamil termasuk kelompok yang memiliki risiko tinggi mengalami anemia.(Wati, Febry \& Rahmiwati 2016)

Adapun data status anemia pada responden pada penelitian ini diketahui melalui hasil pengukuran kadar hemoglobin ibu hamil. Menurut tabel 1 ditemukan ibu hamil anemia sebanyak 16 orang $(32 \%)$. Hal ini menunjukkan bahwa sebagian besar responden tidak mengalami anemia pada masa kehamilan. Hal ini dapat dipengaruhi oleh usia usia kehamilan. Sebagian besar responden berada pada usia kehamilan trimester 1 dan 2 (56\%), yang mana memiliki potensi anemia lebih rendah dibandingkan pada kehamilan trimester 3.(Wati, Febry \& Rahmiwati 2016)

Tabel 2. Tabulasi Silang Status Ketahanan Pangan Rumah Tangga dengan Status Anemia Ibu Hamil di Desa Bektiharjo Tahun 2019

\begin{tabular}{|c|c|c|c|c|c|c|c|}
\hline \multirow{3}{*}{ Status Ketahanan Pangan Rumah Tangga } & \multicolumn{3}{|c|}{$\begin{array}{c}\text { Status Anemia Ibu } \\
\text { Hamil }\end{array}$} & & \multicolumn{2}{|c|}{ Total } & \multirow{3}{*}{$p$ value } \\
\hline & \multicolumn{2}{|c|}{ Anemia } & \multicolumn{2}{|c|}{$\begin{array}{c}\text { Tidak } \\
\text { Anemia }\end{array}$} & \multirow{2}{*}{$\mathbf{N}$} & \multirow{2}{*}{$\%$} & \\
\hline & $\mathbf{n}$ & $\%$ & $\mathbf{n}$ & $\%$ & & & \\
\hline Tahan pangan & 3 & 11,1 & 24 & 88,9 & 27 & 100 & \\
\hline Rawan pangan tanpa kelaparan & 10 & 52,6 & 9 & 47,4 & 19 & 100 & \\
\hline Rawan pangan dengan kelaparan tingkat sedang & 3 & 75 & 1 & 25 & 4 & 100 & 0,019 \\
\hline Rawan pangan dengan kelaparan tingkat & 0 & 0 & 0 & 0 & 0 & 0 & \\
\hline
\end{tabular}

Menurut hasil tabulasi silang pada tabel 2 diketahui bahwa dari total ibu hamil yang mengalami anemia, 13 di antaranya dalam kondisi rawan pangan. Jika dilihat dari keseluruhan ibu hamil yang tidak mengalami anemia, sebagian besar berasal dari rumah tangga yang tahan pangan. Hal ini menunjukkan adanya kecenderungan bahwa ibu hamil yang berada pada kondisi keluarga rawan pangan berpotensi mengalami anemia dibandingkan yang tahan pangan. Melalui uji statistik product moment pearson diketahui $p$ value $=0,019(<0,005)$ dengan besar korelasi $-0,331$. Hasil tersebut mengindikasikan bahwa terdapat hubungan yang signifikan antara status ketahanan pangan rumah tangga dengan anemia pada ibu 
hamil. Adapun korelasi kedua variabel tersebut adalah berhubungan terbalik karena nilainya negatif, yang menunjukkan bahwa semakin rendah skor US-HFSSM maka semakin tinggi kadar hemoglobin. Hal ini dapat dimaknai bahwa semakin tahan pangan suatu rumah tangga maka semakin kecil potensi ibu hamil mengalami anemia.

Hasil penelitian ini memiliki kesamaan dengan beberapa penelitian sebelumnya. Beberapa penelitian serupa juga telah dilakukan untuk mengetahui hubungan ketahanan pangan dengan anemia khususnya pada wanita usia subur. Salah satu penelitian dilakukan pada perempuan usia produktif di Meksiko menunjukan hasil bahwa perempuan yang berstatus rawan pangan sedang dan berat memiliki kemungkinan risiko anemia kekurangan zat besi 33\% dan 36\% lebih besar dibandingkan dengan yang berstatus tahan pangan.(Fischer 2014) Penelitian lain juga menyebutkan bahwa ditemukannya hubungan positif antara rumah tangga rawan pangan dengan anemia pada perempuan usia produktif (15-49 tahun) di Banglades.(Ghose et al. 2016) Penelitian tersebut menyebutkan bahwa perempuan yang mengalami rawan pangan berisiko mengalami anemia 1,6 kali lebih besar dibandingkan yang tahan pangan. Penelitian serupa dilakukan di Brazil menyimpulkan bahwa kemungkinan perkembangan anemia pada wanita hamil lebih tinggi secara signifikan terutama pada situasi rawan pangan, tanpa adanya prenatal care maupun suplementasi zat besi, serta multipara atau wanita yang sudah pernah melahirkan lebih dari sekali.(Demétrio, Teles-Santos \& Santos 2017)

Adapun penelitian ini memiliki kelebihan dan juga kekurangan. Salah satu kelebihan pada penelitian ini adalah proses pengambilan data primer yang mencakup wawancara kuesioner maupun tes hemoglobin pada responden dilakukan secara door-to-door sehingga pelaksanaan lebih fokus dan kondusif. Adapun kekurangan dari penelitian ini adalah jumlah sampel yang tidak terlalu besar.

\section{KESIMPULAN}

Berdasarkan hasil penelitian yang telah dilakukan ditemukan adanya hubungan yang signifikan antara status ketahanan pangan rumah tangga dengan anemia pada ibu hamil. Semakin tahan pangan suatu rumah tangga ibu hamil maka semakin rendah risiko mengalami anemia, khususnya anemia kekurangan zat besi. Makanan sumber zat besi heme yang baik ada pada pangan hewani yang relatif memiliki harga lebih mahal dibanding jenis pangan lainnya. Oleh karena itu sebaiknya ibu hamil juga disarankan mengonsumsi makanan sumber zat besi non heme dan bahan makanan yang mampu berperan sebagai enhancer penyerapan zat besi karena memiliki kecenderungan harga lebih murah atau terjangkau. Ibu hamil juga sebaiknya menghindari bahan pangan yang bersifat inhibitor zat besi.

\section{ACKNOWLEDGEMENT}

Penulis berterima kasih atas segala bantuan yang telah diberikan oleh pihak puskesmas, ibu kader posyandu dan responden. Penghargaan juga diberikan untuk semua staf pengajar Program Studi S1 Gizi Fakultas Kesehatan Masyarakat Universitas Airlangga atas dukungan dan bimbingan yang diberikan.

\section{REFERENSI}

Access, O. 2018, Hubungan Konsumsi Sumber Pangan Enhancer dan Inhibitor Zat Besi dengan Kejadian Anemia pada Ibu Hamil Relation of Iron Enhancer and Inhibitor Food Consumption with Anemia in Pregnant Women, pp. 283-91.

Anemia, K. 1989, Anemia defisiensi besi, pp. 140-5.

Ariani, M., Suryana, A., Suhartini, S.H. \& Saliem, H.P. 2018, PENDAPATAN DI TINGKAT RUMAH TANGGA Performance of Animal Food Consumption based on Region and Income at Hoousehold Level, vol. 16, no. 2, pp. 147-63.

Demétrio, F., Teles-Santos, C. \& Santos, D. 2017, 'Food Insecurity, Prenatal Care and Other Anemia Determinants in Pregnant Women from the NISAMI Cohort, Brazil: Hierarchical Model Concept', Revista Brasileira de Ginecologia e Obstetrícia / RBGO Gynecology and Obstetrics, vol. 39, no. 08, pp. 384-96.

Diana Sukmaningtiyas 2015, Hubungan Antara Tingkat Pengetahuan Dan Status Gizi Ibu Hamil Dengan Kejadian Anemia Di Puskesmas Gatak Kabupaten Sukoharjo, pp. 2-13.

Du, S., Zhai, F., Wang, Y. \& Popkin, B.M. 2000, 'Current Methods for Estimating Dietary Iron 
Bioavailability Do Not Work in China', The Journal of Nutrition, vol. 130, no. 2, pp. 193-8.

Fan, S. \& Brzeska, J. 2016, 'Sustainable food security and nutrition : Demystifying conventional beliefs', Global Food Security, vol. 11, pp. 11-6.

Fischer, N.C. 2014, Household Food Insecurity And Iron Deficiency Anemia In Mexican Women Of Reproductive Age, no. January.

Fitri, Y.P., Briawan, D., Tanziha, I., Madanijah, S., Masyarakat, D.G., Manusia, F.E. \& Bogor, I.P. 2016, TINGKAT KECUKUPAN DAN BIOAVAILABILITAS ASUPAN ZAT BESI PADA IBU HAMIL DI KOTA TANGERANG Adequacy and Bioavailability of Iron Intake among Pregnant Women in Tangerang, vol. 12, no. 3, pp. 185-91.

Furkon, L.A., Perlu, M. \& Ilmu, M. 2014, 'Mengenal Zat Gizi', Ilmu Kesehatan Gizi, pp. 1-53.

Ghose, B., Tang, S., Yaya, S. \& Feng, Z. 2016, 'Association between food insecurity and anemia among women of reproductive age', PeerJ, vol. 2016, no. 5, pp. 1-12.

Kusuma, R., Khomsan, A. \& Kustiyah, L. 2017, 'Konsumsi Ikan Pada Ibu Hamil Dan Kaitannya Dengan Outcome Kelahiran', Media Kesehatan Masyarakat Indonesia, vol. 13, no. 4, p. 295.

Maret, U.S. 2011, AGNES YUDANINGRUM W H 0307029 FAKULTAS PERTANIAN.

Maternal, S.A., Community, N., Approved, P., Health, S.A., Strategic, Q. \& Committee, G. 2019, Clinical Guideline.

'No title' 2012.

Pada, T. 2018, Profil Kemiskinan di Kabupaten Tuban Maret 2017 Persentase di Kabupaten, no. 01, pp. $1-7$.

Perdagangan, K., Badan, S., Perdagangan, P., Komoditi, B. \& Ekonomi, D.I. 2014, Artikel diterima Februari 2013 Artikel disetujui untuk dipublikasikan Juli 2014, vol. 3, no. 1, pp. 42-63.

RI, K.K. 2018, Hasil Utama Riskesdas 2018, Penelitian dan Pengembangan Kesehatan.

Seimbang, P.G. 2014, BERITA NEGARA, no. 1110, pp. 1-97.

Situasi, K.P. \& Masyarakat, D.A.N.P. 2008, Ketahanan pangan: situasi, permasalahan, kebijakan, dan pemberdayaan masyarakat, vol. 9, no. 1.

Suryanty, M. \& Reswita, . 2016, 'Analisis Konsumsi Pangan Berbasis Protein Hewani Di Kabupaten Lebong: Pendekatan Model Aids (Almost Ideal Demand System)', Jurnal AGRISEP, vol. 15, no. 1, pp. 101-10.

Timur, J. 2018, Profil Kemiskinan di Jawa Timur Maret 2018, no. 45, pp. 1-8.

Wati, D.W., Febry, F. \& Rahmiwati, A. 2016, Pada Ibu Hamil Di Wilayah Kerja Puskesmas Gandus Palembang Factors of Iron Deficiency on Pregnant Woman in Gandus Public Health Center Working Area in Palembang, vol. 7, pp. 42-7.

Yusuf, R. 2011, TINGKAT KESEJAHTERAAN DAN KETAHANAN PANGAN RUMAHTANGGA NELAYAN MISKIN : Studi Kasus di Kelurahan Marunda Baru , DKI Jakarta dan Desa Tanjung Pasir, Banten, vol. 6, no. 1, pp. 83-102. 